\title{
The effects of radial bowing and complications in intramedullary nail fixation of adult forearm fractures
}

\author{
Erişkin önkol kırıklarının intramedüller çivi ile sabitlenmesinde \\ radial eğimin etkileri ve komplikasyonlar
}

\author{
Ali Çağdaş Yörükoğlu, MD., ${ }^{1}$ Ahmet Fahir Demirkan, MD., ${ }^{1}$ Alp Akman, M.D., ${ }^{1}$ \\ Ali Kitiş, MD., ${ }^{2}$ Hande Usta, MD. ${ }^{2}$ \\ 1Department of Orthopedics and Traumatology, Medical Faculty of Pamukkale University, Denizli, Turkey \\ ${ }^{2}$ Department of Physical Therapy and Rehabilitation, Medical Faculty of Pamukkale University, Denizli, Turkey
}

\begin{abstract}
Objectives: This study aims to evaluate the effects of radial bowing changes on fracture healing and functional results in adult forearm intramedullary nail applications and complications of forearm nails that have been discussed rarely in the literature.

Patients and methods: Twenty-three patients -11 with isolated radius and 12 with both radius and ulna fractures- (17 males, 6 females; mean age 38.6 years; range 18 to 69 years) who were operated between September 2009 and August 2014 were included in the study. The effects of radial bowing changes on bone healing rates, time to union, and functional levels of the forearm as well as complications of forearm nails were evaluated.
\end{abstract}

Results: We observed fracture healing without any complication in 20 patients $(86.9 \%)$ and nonunion in three patients $(13.1 \%)$ although six months had passed after the operation. Statistically significant difference was detected between radial bowing change and nonunion $(\mathrm{p}=0.01)$. Two patients $(8.6 \%)$ with AO/OTA Classification (The Arbeitsgemeinschaft für Osteosynthesefragen [AO]/Orthopaedic Trauma Association [OTA] Classification), type B3 forearm double fractures had synostosis. Extensor pollicis longus tendon rupture or impingement was detected in six patients (26.8\%) for which nails were applied on radius fracture.

Conclusion: Intramedullary nail application may be an appropriate treatment alternative in forearm fractures with their high healing rates; however, synostosis may arise with its use in wedge fractures (AO/OTA type B3) at the same level. Although radial bowing changes do not have a significant effect on ranges of motion of the forearm, it should be kept in mind that fracture healing may be affected adversely in patients with radial bowing changes of high rates. Complications regarding extensor pollicis longus tendon may develop during intra- or postoperative periods in patients for which a radius nail has been applied.

Keywords: Forearm injuries; fracture fixation; intramedullary; radial bowing; synostosis.

\section{ÖZ}

Amaç: Bu çalışmada erişkin önkol intramedüller çivi uygulamalarında radial eğim değişimlerinin kırık iyileşmesine ve fonksiyonel sonuçlara etkileri ve literatürde pek az tartışılmış olan önkol çivilerinin komplikasyonları değerlendirildi.

Hastalar ve yöntemler: Eylül 2009 - Ağustos 2014 tarihleri arasında ameliyat edilen, 11'i izole radius, 12'si önkol çift kırığ olan 23 hasta (17 erkek, 6 kadın; ort. yaş 38.6 yıl; dağılım 18-69 yıl) çalışmaya alındı. Radial eğim değişimlerinin kırık kaynaması oranlarına, kaynama zamanına ve önkol fonksiyonel düzeylerine olan etkileri ve önkol çivilerinin komplikasyonları değerlendirildi.

Bulgular: Yirmi hastada (\%86.9) herhangi bir komplikasyon olmadan kırık kaynaması olduğu, üç hastada ameliyattan sonra altı ay geçmesine rağmen kaynama olmadığı görüldü (\%13.1). Radial eğim değişimi ile kaynamama arasında istatistiksel olarak anlamlı ilişki bulundu $(\mathrm{p}=0.01)$. AO/OTA Classification (The Arbeitsgemeinschaft für Osteosynthesefragen [AO]/ Orthopaedic Trauma Association [OTA] Classification), tip B3 önkol çift kırıklı iki hastada (\%8.6) sinostoz vardı. Radius kırığına çivi uygulanan altı hastada (\%26.8) ekstansör pollicis longus tendon kopması veya basısı olduğu saptandı.

Sonuç: İntramedüller çivi uygulaması önkol kırıklarında yüksek kaynama oranları ile uygun bir tedavi yöntemi olabilir, fakat aynı seviyede kelebek fragmanlı kırıklarda (AO/OTA tip B3) kullanımında sinostoz gelişebilmektedir. Radial eğim değişimlerinin önkol hareket açıklıkları üzerine belirgin etkisi bulunmamakla beraber, yüksek oranlarda radial eğim değişimleri olan hastalarda kırık kaynamasının olumsuz etkilenebileceği akılda tutulmalıdır. Radius çivisi uygulanan hastalarda ameliyat sırası veya sonrası dönemde ekstansör pollicis longus tendonu ile ilgili komplikasyonlar ortaya çıkabilmektedir.

Anahtar sözcükler: Önkol yaralanmaları; kırık sabitlenmesi; intramedüller; radial eğim; sinostoz.

- Received: June 09, 2016 Accepted: October 28, 2016

- Correspondence: Ahmet Fahir Demirkan, MD. Pamukkale Üniversitesi Tıp Fakültesi Ortopedi ve Travmatoloji Anabilim Dalı, 20160 Kınıklı, Denizli, Turkey. Tel: +90 258 - 2966000 / 5668 e-mail: fahirdemirkan@yahoo.com 
The use of intramedullary nails (IMNs) has proved its success in fractures of long bones such as femur and tibia. ${ }^{[1]}$ However, it continues to be a controversial issue in forearm fractures for surgeons. Intramedullary nailing is advantageous as it heals with less scar tissue cosmetically and does less harm to soft tissue while not impairing blood circulation. Its ability to increase secondary callus formation and decrease refracture rates are also among its advantages. ${ }^{[2]}$ Use of IMNs for forearm fractures has gradually increased with the development of new generation nails. A problem limiting the use of first-generation nails is the necessity for nails to pre-bent for each patient. ${ }^{[3]}$ Previously bent nails give a standard bowing for each patient. The need for distal locking vanishes with the use of previously bent nails as revealed with the change in inclination in bowed bones. Inappropriate restoration of radial bowing may result in axialrotational malalignment, nonunion, and poor forearm functions. ${ }^{[4]}$ In this study, we aimed to evaluate the effects of radial bowing changes on fracture healing and functional results in adult forearm IMN applications and complications of forearm nails that have been discussed rarely discussed in the literature.

\section{PATIENTS AND METHODS}

\section{Patients}

Twenty three patients with acute adult forearm diaphyseal fractures -11 with isolated radius and 12 with both-bone forearm fractures- (17 males, 6 females; mean age 38.6 years; range 18 to 69 years) who were operated between September 2009 and August 2014 at Medical Faculty of Pamukkale University participated in this retrospective study. The study protocol was approved by the Non-invasive Medical Ethics Committee. A written informed consent was obtained from each patient. The study was conducted in accordance with the principles of the Declaration of Helsinki. Inclusion criteria were normal forearm function prior to trauma and postoperative follow-up for at least a year. Type 2 or 3 open fractures and fractures involving the joint and Galeazzi and Monteggia fractures were excluded. All fractures were stabilized with an interlocking IMN system (Acumed, Hilsboro, Oregon, USA). Mean days from fracture until surgery was $3.3 \pm 4.2$ days (range 1-19 days). Mean follow-up period was 31 \pm 16 months (range 12-71 months). While 16 patients $(70 \%)$ had isolated forearm fractures, seven $(30 \%)$ had multiple fractures. According to AO/OTA Classification (The Arbeitsgemeinschaft für Osteosynthesefragen [AO]/ Orthopaedic Trauma Association [OTA] Classification), nine patients had type A (seven A2 and two A3), 11 patients had type $\mathrm{B}$ (three $\mathrm{B} 2$ and eight $\mathrm{B} 3$ ), and three patients had type $\mathrm{C}$ (one $\mathrm{C} 1$, one $\mathrm{C} 2$, and one $\mathrm{C} 3$ ) fractures (Table I).

\section{Surgical procedure}

Patients of this study had acute fractures. All of the patients were operated by one surgeon using closed surgical techniques with fluoroscopy. For radius fractures, entrance point was $5 \mathrm{~mm}$ proximal to the articular surface of radius and ulnar to Lister tubercle as described previously. ${ }^{[5]}$

\section{Assessment methods}

Forearms of all the patients were evaluated by anterior-posterior and lateral comparative radiographs

TABLE

Relationship among radial bowing, grip and pinch strength, functional status and patient satisfaction

\begin{tabular}{lcccc}
\hline & \multicolumn{3}{c}{ Radial bowing change (\%) } \\
\cline { 2 - 5 } & Mean \pm SD & Range & $r^{*}$ & $p$ \\
\hline Grip strength & $28.1 \pm 14$ & $3-52.6$ & -0.50 & 0.02 \\
Pinch strength & & & & \\
$\quad$ Nail to nail & $3.3 \pm 1.9$ & $0.5-7.6$ & -0.52 & 0.18 \\
$\quad 1^{\text {st }}$ pulp to $2^{\text {nd }}$ pulp & $4.1 \pm 2.4$ & $0-8.6$ & -0.47 & 0.03 \\
$\quad 1^{\text {st }}$ pulp to 3rd pulp & $3.0 \pm 1.6$ & $0-5.3$ & -0.48 & 0.03 \\
Forearm ROM & & & & \\
Pronation & $72.2 \pm 19.8$ & $28-90$ & 0.27 & 0.2 \\
Supination & $75.3 \pm 24.7$ & $0-90$ & 0.34 & 0.3 \\
Michigan (total score) & $61.5 \pm 23.2$ & $9.4-90.8$ & -0.60 & 0,00 \\
DASH-T & $31.2 \pm 24.9$ & $4.5-90.9$ & 0.56 & 0.01 \\
Patient satisfaction & $7.6 \pm 2.3$ & $1-10$ & 0.35 & 0.12 \\
\hline
\end{tabular}

SD: Standard deviation; * Spearman's correlation analysis was used; ROM: Range of motion; DASH-T: Disability of the Arm, Shoulde and Hand. 
from $100 \mathrm{~cm}$ distance in the same position. In postoperative control radiographs, radial bowing was measured by detecting three points in the radial cortex via completing radial-ulnar cortex to the full circle and diameter differences were determined with the help of an analytic program (Hot Door CAD tools [Hot Door, CA, USA] loaded Adobe Illustrator [Adobe, CA, USA]) (Figure 1). The diameter change rates of the operated bones were compared with contralateral forearm. Bone healing rate, time to union, and functional status of the forearm (compared with contralateral side) were assessed. ${ }^{[4,6]}$ Early- and lateterm complications were also noted. For the functional results, the Grace-Eversmann Scoring System ${ }^{[7]}$ that is based on bone union and forearm rotation was used. Bone union and forearm rotation as much as $90 \%$ of the contralateral arm was evaluated as 'perfect', $80-60 \%$ was evaluated as 'good,' and under $60 \%$ or no union was evaluated as a 'poor' result. Patient satisfaction was determined by describing their upper extremity current satisfaction levels on a 10-point horizontal line (i.e., very good; 10 -insufficient; 0). For the functional evaluation of the upper extremity, the Turkish version of the Disability of the Arm, Shoulder and Hand (DASH-T) questionnaire and Michigan Hand Outcomes Questionnaire (MHOQ) were used at the $12^{\text {th }}$ week. The grip strengths were measured with a hydraulic hand dynamometer (Jamar, Sammons Preston, Inc., Bolingbrook, IL, USA) and range of motion (flexion, extension, supination and pronation) with a goniometer. The measurements were performed on both arms.

\section{Statistical analysis}

Statistical analysis of the data was performed using PASW version 17.0 (SPSS Inc., Chicago, IL, USA).
Spearman's correlation analysis was used for correlation between parameters. Data were analyzed within $95 \%$ confidence interval and $p<0.05$ value was considered as the significance level in evaluation of the results.

\section{RESULTS}

Healing times in isolated radius diaphyseal and both-bone forearm fractures were 8.6 weeks and 11.6 weeks, respectively. Healing without any complication was determined in 20 patients $(86.9 \%)$ while nonunion was determined in three patients (13.1\%; two with both-bone forearm fractures and one with isolated radius diaphyseal fracture) at six months postoperatively. Synostosis was observed in two patients with double forearm fractures (8.6\%); fractures of these patients were at the same level of AO type B3 fracture (Figure 2). Complications regarding extensor pollicis longus (EPL) were encountered in six out of a total of 23 patients (26.8\%) to whom nails were applied for fixation of radius or both-bone forearm. Tearing of the tendon during the operation due to injury occurred in one of these patients and early rupture in the postoperative third week in one patient. Extensor pollicis longus tendons in three patients were not functioning and one patient had the sensation of being triggered with thumb movements at the late postoperative period. The mean DASH-T and MHOQ total scores were $31.2 \pm 24.9$ and $61.5 \pm 23.2$, respectively. Grip strengths on the affected and unaffected sides were $28.1 \pm 14.4 \mathrm{~kg}$ and $34.8 \pm 13.8 \mathrm{~kg}$, respectively. Mean increase rate of the diameter of radial bowing was $19.6 \pm 15.2 \%$ (1.01-55.9) in patients with bone healing, while mean increase rate of the diameter of radial bowing in patients without bone healing was (a)

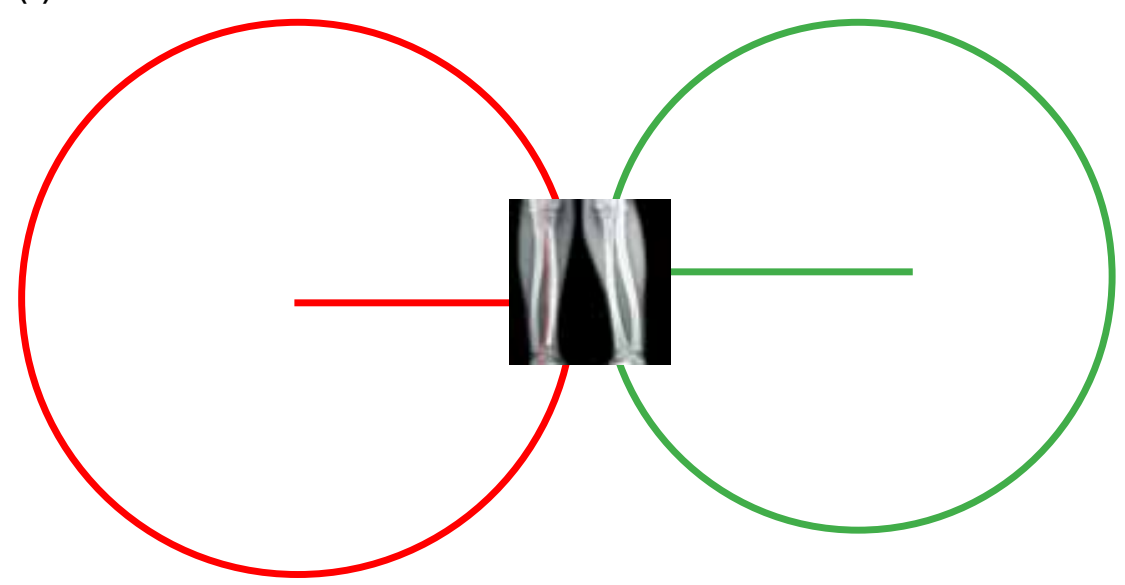

(b)

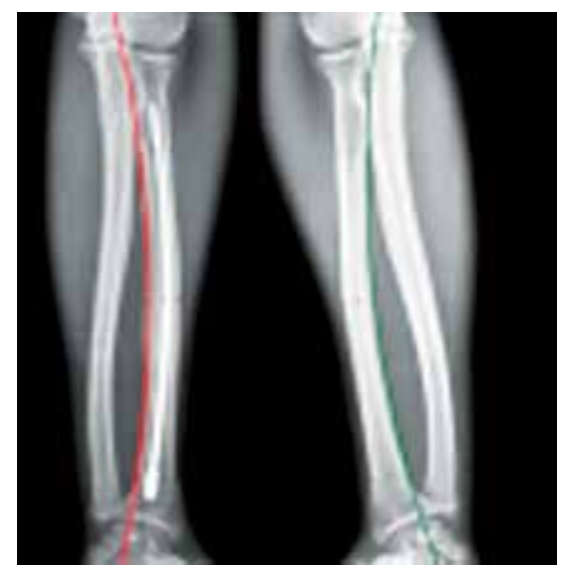

Figure 1. . Measurement of radial bowing in a patient with radial fracture; (a) in global view and (b) in closed view (measurement points were marked with dashed lines). 

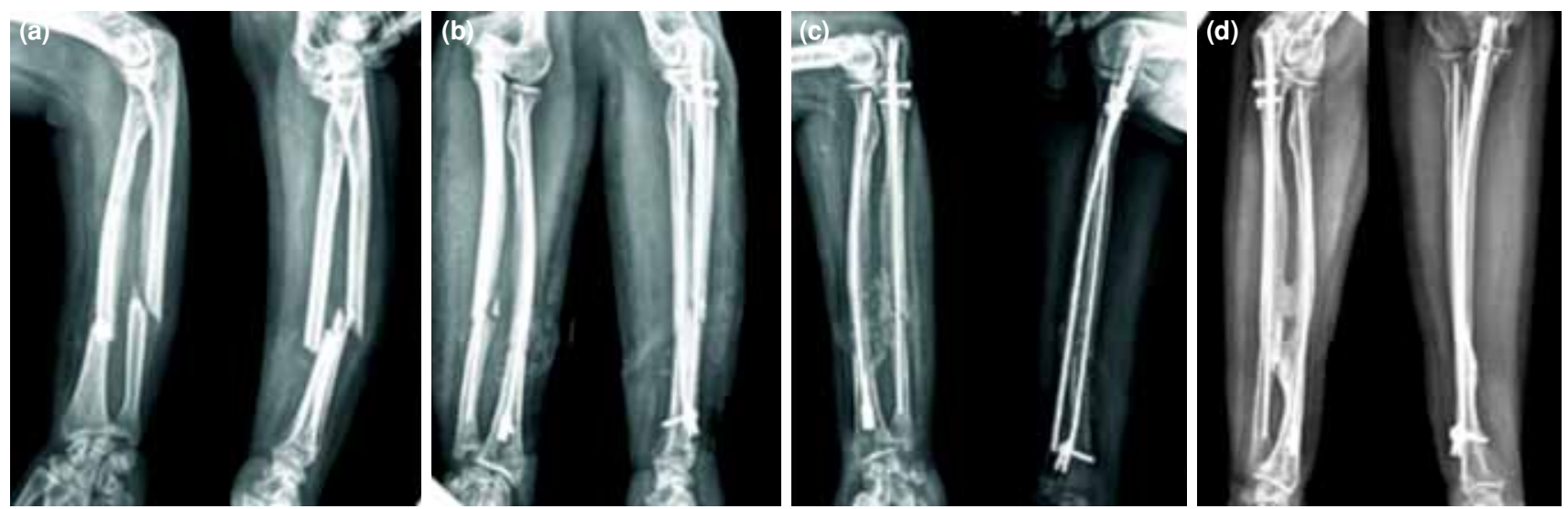

Figure 2. A 35-year-old male patient with both-bone forearm fracture Arbeitsgemeinschaft für Osteosynthesefragen type B3 fixed with closed forearm nailing resulted in union with synostosis; (a) preoperative radiogram, (b) postoperative first day radiogram, (c) postoperative second month radiogram, and (d) postoperative first year radiogram.

$147.3 \pm 17.4 \%$ (129.5-164.4). A statistically significant relationship was observed between radial bowing change and nonunion ( $\mathrm{p}=0.01)$. No relationship was found among radial bowing change and range of motion such as pronation and supination and level of satisfaction. A relationship between radial bowing with grip and pinch forces has been observed. A significant relationship among MHOQ and DASH-T questionnaire scores with radial bowing change was found (Table I). According to the Grace-Eversmann scoring system, $30.4 \%$ poor results, $4.3 \%$ good results, and $65.2 \%$ perfect results were obtained.

\section{DISCUSSION}

Intramedullary nail application may be a treatment alternative in forearm fractures with their high healing rates; however, radial bowing changes may have an adverse effect on fracture healing. Radial bowing changes may not have a significant effect on range of motion of the forearm while they may affect pinch and grip strength of the extremity.

Intramedullary nail fixation of both-bone forearm fractures offers several theoretical advantages including smaller incisions, the potential to avoid damaged overlying skin, no periosteal stripping, promotion of healing with intramedullary reaming, and implantation of a load-sharing device in amenable comminuted fractures ${ }^{[8]}$ The normal radial bow of the bone might not be fully restored because of the small diameter of the IMN ( 3.0 or $3.6 \mathrm{~mm}$ ), the change of nail contour during insertion, and the wide medullary canal of the radius, especially in the distal third of the radius. ${ }^{[9]}$ A good functional result (more than $80 \%$ of normal rotation of the forearm) was associated with restoration of the normal amount and location of the radial bow. Similarly, the recovery of grip strength was associated with restoration of the location of the radial bow toward normal. ${ }^{[4]}$ It was proposed that forearm functions were related with early motion rather than bowing. ${ }^{[10]}$ Poor restoration may result in decreased rotation, especially pronation, and decreased grip strength, leading to worse patient outcomes. ${ }^{[1]}$ Matthews et al. ${ }^{[12]}$ described the effect on supination and pronation of angular malalignment of forearm and indicated that ten degrees angulation in any direction causes little loss of forearm rotation, whereas 20 degrees angulation causes important loss of forearm rotation. In our study, a significant relationship has been observed between radial bowing and grip-pinch forces, MHOQ total and DASH-T questionnaire scores. Radial bowing was calculated by completing a full circle with radial cortical three-point labeling with the aid of an analytic program that is different from that in other studies, but functions with the same principle. This method might be easier for the calculation of bowing. According to previous studies, fractures in forearm bones healed in 10 weeks to 14 weeks. In our cases, mean healing time was similar with the literature (Table I). ${ }^{[13,14]}$

Radio-ulnar synostosis may occur with $1 \%$ to $8 \%$ of fractures of the forearm with any method of treatment, but it is more common with proximal fractures, high-energy trauma, infection, concomitant head injuries, in severely comminuted or open fractures, and open reduction. ${ }^{[15]}$ Despite the abundant callus, Lee et al. ${ }^{[16]}$ did not encounter any limitation or synostosis in any patient. Synostosis was observed in two patients with both-bone forearm fractures in our series. All of these patients were cases with $\mathrm{AO}$ type $\mathrm{B} 3$ type butterfly fragment and 
none of them had head trauma. In forearm fractures at the same level, injuries in which the interosseous membrane is also damaged or cases with butterfly fragment may be considered as risk factors in terms of synostosis. ${ }^{[9,13]}$

Injury to EPL tendon has not been dwelt on sufficiently in previous publications as an important complication of radial nailing. Rupture of the EPL tendon may occur during intra- and postoperative periods due to the close relation of entry of the nail to the Lister tubercle and EPL tendon. The implant or bone spur formed at the entry point abrades the EPL tendon, which ends with rupture of the tendon. Also, it may be due to poor vascularity around Lister tubercle or impairment of vascularity. In a recent study, nine cases of rupture of EPL tendon following dorsal entry flexible nailing of radial shaft fractures in children have been reported. ${ }^{[17]}$ Extensor pollicis longus rupture may be more common than reported in the literature and to prevent this significant complication, a radial entry point is recommended. ${ }^{[17]}$ The high incidence of EPL rupture may be due to our technical errors leading to tendon irritation related to prominent implant or related to ulnar entry point as described in the surgical technique of the nail used. Extensor pollicis longus ruptures have been reported previously with different designs of nails all inserted from the fourth compartment ulnar to Lister tubercle. ${ }^{[18]}$

The retrospective study design and the small number of patients constitute the limitations of our study. However, to the best of our knowledge, radial bowing differences between contralateral extremities have not been discussed in normal individuals yet. In this study, radial bowing changes were performed in comparison with the bowing of the uninvolved extremity as described before..$^{[5]}$

In conclusion, IMN application may be an appropriate treatment alternative in forearm fractures with their high healing rates; however, synostosis may arise with its use in wedge fractures (AO type B3) at the same level. Although radial bowing changes may not have a significant effect on ranges of motion of the forearm, fracture healing may be affected adversely as well as grip and pinch forces. Complications regarding EPL may develop during intra- and postoperative periods in cases for which a radius rod is applied.

\section{Declaration of conflicting interests}

The authors declared no conflicts of interest with respect to the authorship and/or publication of this article.

\section{Funding}

The authors received no financial support for the research and/or authorship of this article.

\section{REFERENCES}

1. Karakaşli A, Satoğlu İS, Havitçioğlu H. A new intramedullary sustained dynamic compression nail for the treatment of long bone fractures: a biomechanical study. Eklem Hastalik Cerrahisi 2015;26:64-71.

2. Beytemür O, Albay C, Adanır O, Yüksel S, Güleç MA. Is intramedullary nailing applicable for distal tibial fractures with ankle joint extension? Eklem Hastalik Cerrahisi 2016;27:125-31.

3. Moss JP, Bynum DK. Diaphyseal fractures of the radius and ulna in adults. Hand Clin 2007;23:143-51.

4. Schemitsch EH, Richards RR. The effect of malunion on functional outcome after plate fixation of fractures of both bones of the forearm in adults. J Bone Joint Surg Am 1992;74:1068-78.

5. Cossio A, Cazzaniga C, Gaddi D, Zatti G. Treatment of Diaphyseal Forearm Fractures With Intramedullary Nailing. Tech Orthop 2014;29:140-4.

6. Firl M, Wünsch L. Measurement of bowing of the radius. J Bone Joint Surg [Br] 2004;86:1047-9.

7. Grace TG, Eversmann WW Jr. Forearm fractures: treatment by rigid fixation with early motion. J Bone Joint Surg [Am] 1980;62:433-8.

8. Schulte LM, Meals CG, Neviaser RJ. Management of adult diaphyseal both-bone forearm fractures. J Am Acad Orthop Surg 2014;22:437-46.

9. Hong G, Cong-Feng L, Hui-Peng S, Cun-Yi F, Bing-Fang Z. Treatment of diaphyseal forearm nonunions with interlocking intramedullary nails. Clin Orthop Relat Res 2006;450:186-92.

10. Goldfarb CA, Ricci WM, Tull F, Ray D, Borrelli J Jr. Functional outcome after fracture of both bones of the forearm. J Bone Joint Surg [Br] 2005;87:374-9.

11. FA L. Diaphyseal forearm fractures. In: Sanders R, editor. Core Knowledge in Orthopaedics Series: Trauma. Philadelphia: Mosby / Elsevier; 2008. p. 121-38.

12. Matthews LS, Kaufer H, Garver DF, Sonstegard DA. The effect on supination-pronation of angular malalignment of fractures of both bones of the forearm. J Bone Joint Surg [Am] 1982;64:14-7.

13. Weckbach A, Blattert TR, Weisser Ch. Interlocking nailing of forearm fractures. Arch Orthop Trauma Surg 2006;126:309-15.

14. Gao H, Luo CF, Zhang CQ, Shi HP, Fan CY, Zen BF. Internal fixation of diaphyseal fractures of the forearm by interlocking intramedullary nail: short-term results in eighteen patients. J Orthop Trauma 2005;19:384-91.

15. Schatzker J TM. Fractures of the radius and ulna. In: The Rationale of Operative Fracture Care. 3rd ed. New York: Springer; 2005. p. 137-66.

16. Lee YH, Lee SK, Chung MS, Baek GH, Gong HS, Kim $\mathrm{KH}$. Interlocking contoured intramedullary nail fixation for selected diaphyseal fractures of the forearm in adults. J Bone Joint Surg Am 2008;90:1891-8.

17. Brooker B, Harris PC, Donnan LT, Graham HK. Rupture of the extensor pollicis longus tendon following dorsal entry flexible nailing of radial shaft fractures in children. J Child Orthop 2014;8:353-7.

18. Köse A, Aydın A, Ezirmik N, Can CE, Topal M, Tipi T. Alternative treatment of forearm double fractures: new design intramedullary nail. Arch Orthop Trauma Surg 2014;134:1387-96. 